\title{
Quartz- Porphyry Dolerite in A Selected Part of Southern Benue Trough, Nigeria
}

\author{
1. Department of Geology, Faculty of Science, University of Port Harcourt, Port Harcourt, Nigeria. \\ 2. Department of Geology, Federal University of Technology, Owerri, Nigeria.
}

\begin{abstract}
The dolerites in some parts of southern Benue Trough were studied petrographically. The results show that most of the dolerites in the Anambra and Afikpo basins are olivine dolerites except Umuchieze LokpaUkwu that host mostly quartz porphyry dolerites. The thin section results show that the dolerite rocks in Umuchieze LokpaUkwu has mineral paragenesis of plagioclase feldspar+quartz + pyroxene + biotite + hornblende + and hematite. The pore spaces and fractures in the rocks are healed by the infilling of quartz. The porphyritic texture of the dolerite in the study area show variable temperatures of the crystallized magma that formed the dolerite. The sharp contacts of the dolerites and the host rocks could play roles in the alteration of the crystallizing magma. Hydrothermal interaction, contamination and assimilation played major roles in the evolutionary processes of the magma that formed the quartz-porphyry dolerite.
\end{abstract}

Key word: Quartz, Dolerites, Benue Trough, Magma

DOI: 10.7176/JEES/10-2-09

Publication date: February $29^{\text {th }} 2020$

\section{Introduction}

Benue Trough is one of the sedimentary basins in Nigeria in which the sediment thickness is estimated to be about $6,500 \mathrm{~m}$ in some places and was formed by several transgressive and regressive sedimentary cycles (Onwualu-John and Ukaegbu, 2009). The sediments have been affected by compressional deformation during the Santonian times. The Santonian deformation produced the Abakaliki Anticlinorium. Abakaliki Anticlinorium has two syncline or basins, Anambra basin at the western flank and Afikpo basin at the eastern flank. The tectonism that occurred in Benue Trough was accompanied with magmatism and the magmatism resulted to the emplacement of two groups of dolerite (Olivine dolerites and quartz porphyry dolerite) in the study area.

2. There have been diverse views on the origin of Benue Trough. The origin and geology of Benue Trough have been discussed by Etuk et al (2008), Reyment (1965), Wright et al. (1985), Nwajide (1990), Onwualu-John and Ukaegbu (2009), Kogbe (1976). Benue Trough has three segments, the Southern Benue Trough, the Middle Benue Trough and the Northern Benue Trough. The study area (LokpaUkwu) is within the Southern Benue Trough and lies within the Anambra Basin. The Abakaliki Anticlinorium forms the high relief in the study area while the dolerites form a moderate domal height that has intruded the sedimentary sequences. Though much work has been done on the geology of Benue Trough but the study of the quartz porphyry dolerite of this basin is scarce. The scope of this work is to determine the geologic processes that resulted to the Formation of the peculiar quartz - dolerite rock in the study area.

\section{Geologic Setting}

The geology of the Anambra Basin is the Asu River Group which is the oldest sediment, Albian in age, the EzeAku Formation, Nkporo shales, the Mamu Fm, Ajali Fm. and the NsukkaFm. The field relations at Umuchieze LokpaUkwu comprises of dolerites (Quartz porphyry dolerites), The Asu River Group (Albian), Nporo Shale (Turonian) and Mamu Shale (Maastrichtian). 


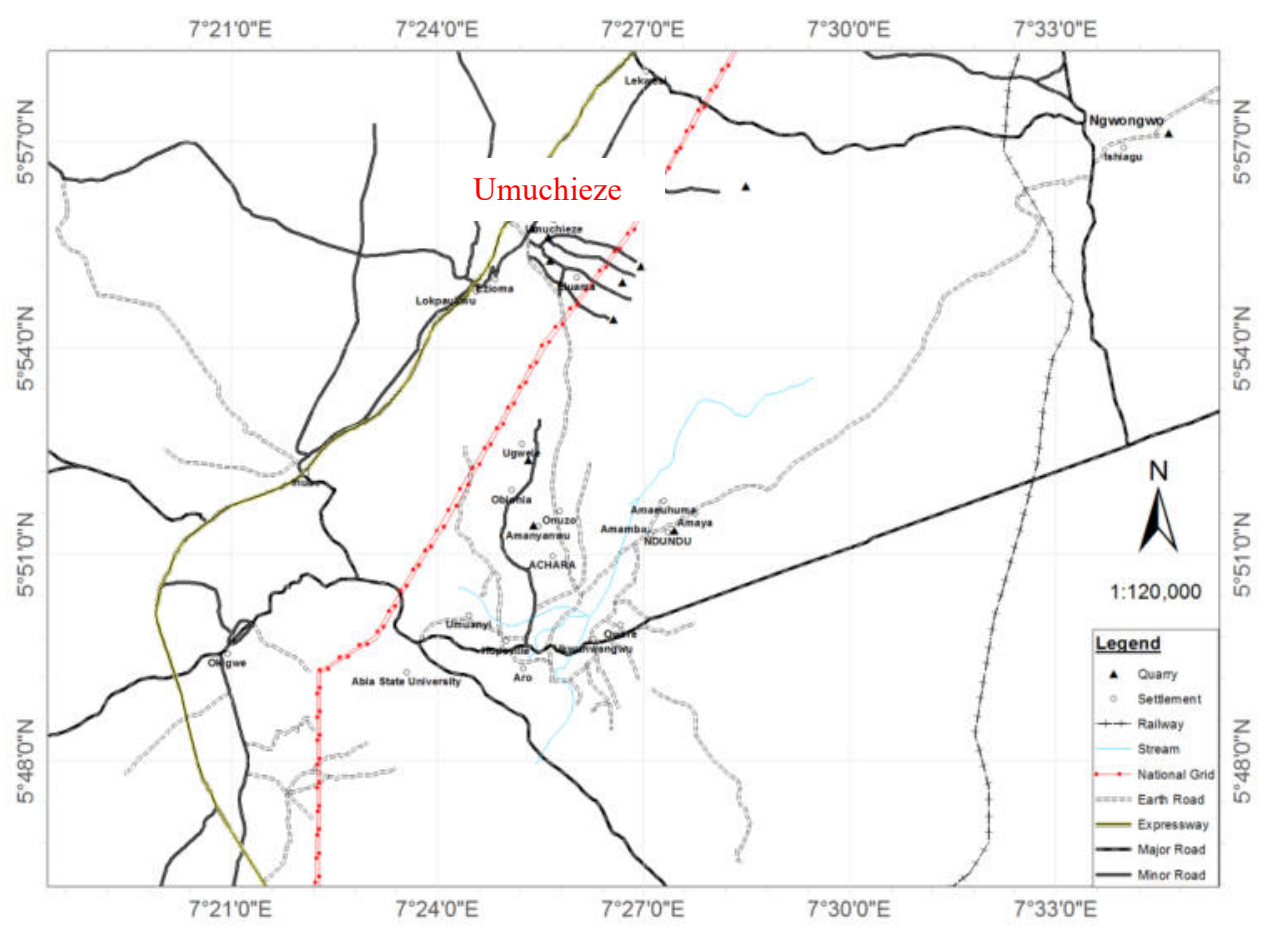

Figure1. Location Map of the study area and environ

\begin{tabular}{|c|c|}
\hline AGE & ABAKALIKI - ANAMBRA BASIN \\
\hline Oligocene & Ogwashi-Asaba Fomation \\
\hline Eocene & $\begin{array}{c}\text { Ameki/Nanka Formation/ } \\
\text { Nsugbe Sandstone } \\
\text { (Ameki Group) }\end{array}$ \\
\hline Palaeocene & $\begin{array}{l}\text { Imo Formation } \\
\text { Nsukka Formation }\end{array}$ \\
\hline Maastrichtian & $\begin{array}{l}\text { Ajali Formation } \\
\text { Mamu Formation }\end{array}$ \\
\hline Campanian & Npkoro Oweli Formation/Enugu Shale \\
\hline \multicolumn{2}{|l|}{ Santonian } \\
\hline Coniacian & Agbani Sandstone/Awgu Shale \\
\hline Turonian & Eze Aku Group \\
\hline $\begin{array}{l}\text { Cenomanian - } \\
\text { Albian }\end{array}$ & Asu River Group \\
\hline $\begin{array}{l}\text { Aptian } \\
\text { Barremian } \\
\text { Hauterivian } \\
\end{array}$ & Unnamed Units \\
\hline ambrian & Basement Complex \\
\hline
\end{tabular}

Figure 2. Stratigraphy of the Southern Benue Trough, Modified from Nwajide, 1990 


\section{Materials and Methods \\ a. Field Method}

Thirteen (13) Fresh rock samples of quartz porphyry dolerites were collected at the igneous suite in Umuchieze LokpaUkwu. The quartz porphyry dolerite occurs as dyke in the sedimentary sequences. There are megascopic minerals of feldspar and quartz in the dolerite. The dolerite intruded the Asu River Group. There is a sharp contact between the dolerite and the host rocks.

\section{b. Thin Section}

The rock samples were cut with cutting machine, and were polished on a flat plate with carborandum to a thickness of $0.33 \mathrm{~mm}$ which can allow light from the petrologic microscope to penetrate the slide. The polished rock samples were mounted on a slide, glued with araldite, and placed on a hot plate to dehydrate water bubbles. Thin Sections of the rocks were prepared and described using petrological microscope. The slides were studied under plane polarized light and crossed polarized light in order to get the holistic optical properties of the minerals in the rock samples.

\section{Results/Discussion}

\subsection{Petrography}

Quartz porphyry dolerites of the study area have large mineral crystals of quartz and plagioclase set in smaller crystals. The essential minerals in the dolerites are plagioclase feldspar, pyroxene, quartz, and other minerals are hornblende, biotite and hematite. The average mineral compositions in the quartz dolerite samples are plagioclase feldspar (45\%), quartz (20\%), pyroxene (10\%), biotite (10\%), hornblende (10\%) and hematite (5\%).

Petrographic studies of dolerites in the Southern Benue Trough have mineral paragenesis of olivine+pyroxene+plagioclase+biotite+hornblend+heamatite ${ }^{+}$-quartz, but Umuchieze in Lokpa-Ukwu of Anambra basin appear to have dolerites that are distinct from other dolerites in the Southern Benue Trough. The quartz porphyry dolerite of the study area has quartz as the essential minerals.

The minerals show diverse optical properties; plagioclase show straight grain boundaries, crystal exhibit albite twinning and subhedral crystals in thin section. Biotite occur as narrow small plates of matrix sizes and exhibit brown colour, it has a perfect cleavage, hematite shows brownish red with a pleochroic colour of yellow, the crystal is euhedral. The pyroxene shows greenish colour, with some parting/or basal cleavage, the crystal system is euhedral and orthorhombic. Hornblende crystal shows hexagonal shape, with greenish colour which shows pleochroic colour of dark brown.

\subsection{Petrogenesis.}

The quartz - porphyry dolerites of LokpaUkwu is characterized by large mineral crystals set in smaller crystals. The variation in the crystal sizes are due to different rates of cooling as the magma evolved. The large crystals grew as the magma cooled slowly in the sub surface but as the magma evolved closer to the surface (at the shallow level), there was a rapid to moderate cooling of the fractionating magma thereby giving rise to minerals of finermedium grain crystals. The phenocrysts in the rocks are quartz and plagioclase while pyroxene, biotite, hornblend, hematite falls within the smaller crystals.

The quartz are glassy in nature while the feldspar are whitish and cloudy. In some samples, the feldspar crystals are larger than the quartz. The quartz are partly rounded while the feldspar are rectangular in shape. The phenocryst of quartz in the rocks probably appear as products of pneumatolytic action by vapor (a process of hydrothermal interaction whereby magma emit gases to the host rocks and crystallizes new minerals thereby bringing secondary changes that led to the deposit of the new minerals, for instance quartz).

The quartz porphyry dolerite of the study area show mineralogical signatures that appear metasomatics. The quartz enrichment in the dolerites could be due to magma fractionation at the channel ways, or assimilation of quartz from the host sedimentary rocks during the magma evolution. Fluid infiltration or diffusion in a crystallizing magma can also result to the enrichment/ mineralization of quartz in the rocks. The rock slides depicts that the quartz porphyry do not only exist at the outer part of the rocks, rather, it extends to the internal sections of the dolerites. 

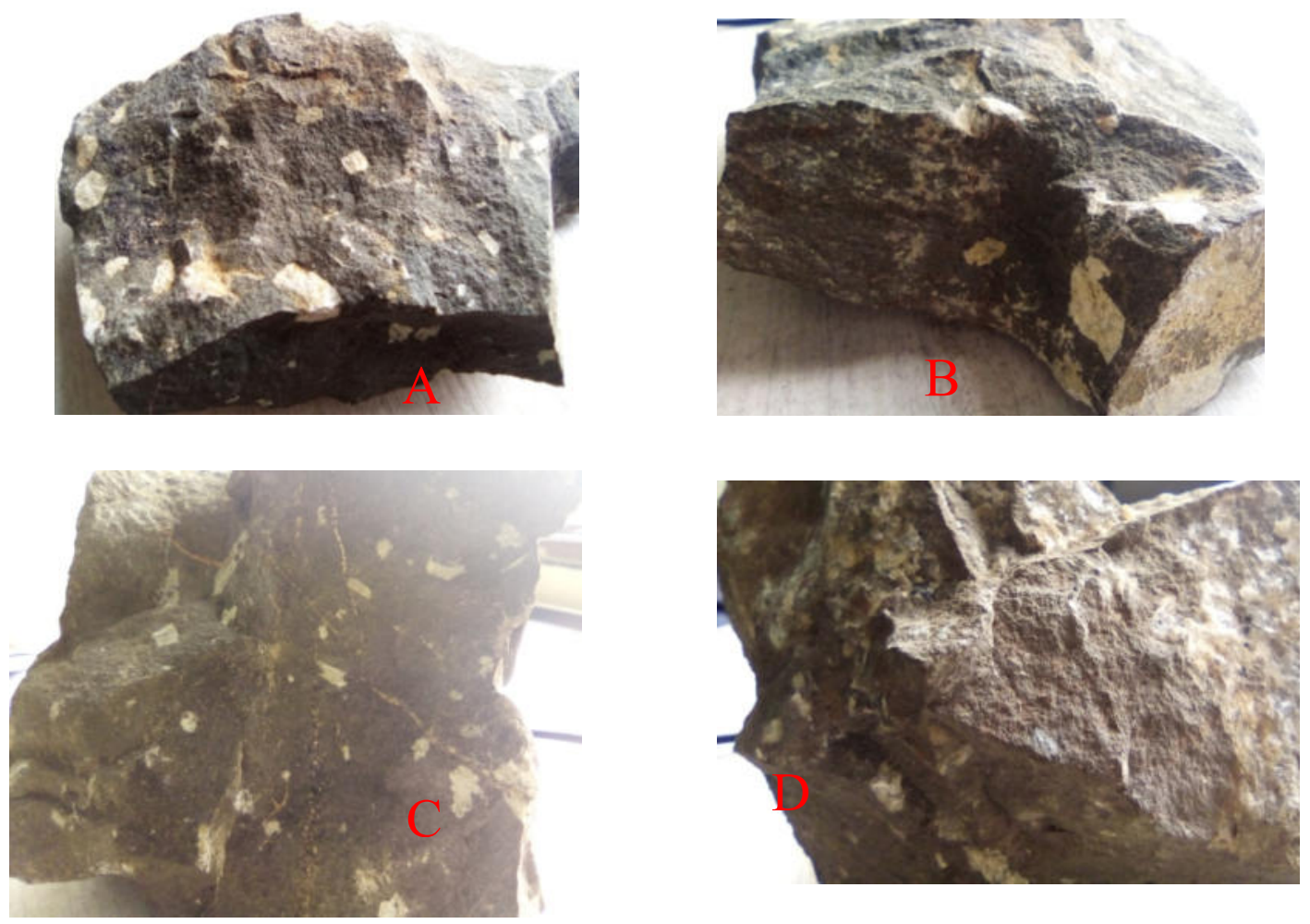

Plate 4 A-D: Pictures of quartz - porphry dolerites of Umuchieze LokpaUkwu

Hydrothermal crystallization of quartz from the cooling solution can be the genesis of the phenocryst of quartz in the doleritic rocks. Hydrothermal fluid which has been altered by earth crust could influx into evolving magma and this process can lead to precipitation of quartz from the hot hydrothermal fluid into the crystallizing magma.

Patent metasomatism occurrence at the mantle could be a possible factor for the dominance of quartz in the doleritic rocks. Jane and Jays(1987) documented that mantle metasomatism occurs as a result of reaction between fluid differentiates of mafic melts and the peridotite rocks, thereby stating that intrusion of mafic melt can result to patent metasomatism. O'Relly (2013) stated that the feature of mantle fluid can be ascertained from the features of the fluid influx in mantle and indirectly from alterations in the chemical features of mantle minerals. It has been suggested that metasomatic media/agent can form in the lithospheric mantle, deep-mantle or subducted oceanic lithosphere (Beccaluvaet al. 2001).

Water is one of the extrusive material that accompanies magmatism in some cases and this water has some dissolved minerals which could be quartz, the presence of this quartz could contribute to anomalous concentration of quartz in the dolerite of the southern Benue Trough. Steven (2015) has stated that when magma erupts with water that contains dissolved minerals, that when the hydrothermal fluids cool, it precipitates minerals on the rocks fractures and pore spaces. Mineralized fluid from the sedimentary host rocks can transport ions into the crystalizing magma thereby forming new minerals in the rocks.

\section{Conclusion}

The occurrence of quartz porphyry dolerites in Umuchieze lokpaUkwu indicates that magmatic evolutionary stages, hydrothermal alterations and late crystallization of magma play major roles during the evolving and crystallization processes of the magma. Prolonged processes of assimilation and contamination of quartz probably resulted to incremental batch crystallization of quartz since quartz crystallizes late and this process can give rise 
to quartz vein or quartz patches of varying shapes and sizes. Moreover, hydrothermal fluids could be components of the magmatic eruption which on interaction with the sedimentary host rocks probably assimilate quartz into the cooling solutions thereby forming the phenocrysts of quartz found in the porphyry dolerites. The quartz porphyry dolerites of Umuchieze LokpaUkwu can be described as hybrid dolerites.

\section{References}

Beccaluva, L., Bianchini, G., Coltorti, M., Perkins, W. T.,Siena, F., Vaccaro, C. and Wilson, M.(2001).Multi stage evolution of the European lithospheric Mantle: New evidence from Sardinian Peridotite Xenoliths. Contributions to mineralogy and Petrology. Pp 142-297.

Etuk, E.E, Ukpabi, N., Ukaegbu, V.U., Akpabio I.O.(2008). Structural Evolution, Magmatism, and Effects of Hydrocarbon Maturation in Lower Benue Trough, Nigeria: A case study of LokpaUkwu, Uturu and Ishiagu. The Pacific Journal of Science and Technology. Vo19 No 2. Pp526-532.

Jane E.N and Jays S.N.(1987). "Processes of mantle metasomatism'; Constrainsts from observations of composite Peridotite Xenoliths'Mantle metasomatism and Alkaline magmatism, Ellen Mullen Moris Jill Dill Pasteries.

Kogbe(1976). The Cretaceous and Palaeogene sediment of southern Nigeria. In Geology of Nigeria. C.A.Koge(ed). Lagos: Elizabeth publishing Co.

Nwajide, C.S., (1990). “Cretaceous Sedimentation and Paleography of Central Benue Trough" In : The Benue Trough Structure and Evolution.Ofoegbu, C.O.(ed).19-37

Onwualu-John, J.N and Ukaegbu, V.U. (2009).Petrogenetic and geotectonic Implication of LokpaUkwu pyroclastics Southern Benue Trough,Nigeria. The Pacific journal of science and Technology, 1(1),11-27.

O'Relly, S.Y., and Griffin,W.L (2013). Mantle Metasomatism. In D.E. Harlov and H. Austrheim(Eds.), Metasomatism and the chemical transformation of rock: the role of fluids in terrestrial and extraterrestrial processes.Pp 471-533.

Reyment, R.A., (1965). Aspect of the Geology of Nigeria. Ibadan University Press. Pp 23-70.

Steven E.(2015). Physical Geology Text book. Open. Bcampus.ca

Wright JB,Hastings DA, Jones WB and Williams HR(1985).Geology and Mineral Resources of West Africa. Allen and Unwin 